Institute of $\mathbf{F}_{\text {ood and }} \mathbf{A}_{\text {gricultural }} \mathbf{S}_{\text {ciences }}$

\title{
2003 Handbook of Employment Regulations Affecting Florida Farm Employers and Workers: Transportation of Migrant Farm Workers [State] ${ }^{1}$
}

Leo C. Polopolus, Michael T. Olexa, Fritz Roka, and Carol Fountain ${ }^{2}$

\section{Purpose}

To provide state standards for transporters of migrant farmworkers.

\section{Who Must Comply}

- Any person who transports, contracts, or arranges for the transportation of one or more migrant workers who do not live in the immediate area for planting, cultivating, or harvesting agricultural crops must comply with this state law.

- A migrant farmworker transporting himself or herself and his or her immediate family is exempt from the provisions of this program.

\section{Transporter Requirements}

Transporters must comply with the provisions of Chapter 316.620, Florida Statutes, which provides that:

- Tires must:

- Be adequate for the size and weight of the vehicle.

- Not be smooth or worn so as to expose fabric.

- Have a tread configuration in contact with the road.

1. This is EDIS document FE419, a publication of the Department of Food and Resource Economics, Florida Cooperative Extension Service, Institute of Food and Agricultural Sciences, University of Florida, Gainesville, FL. Published July 2003. This information is included in Circular 1200, Handbook of Employment Regulations Affecting Florida Farm Employers and Workers. First published February 1992 as Circular 1043 . Revised December 2002 as Circular 1200. Please visit the EDIS website at http://edis.ifas.ufl.edu.

2. Leo C. Polopolus, Professor Emeritus, Department of Food and Resource Economics, University of Florida, Gainesville, FL; Michael T. Olexa, Professor, Department of Food and Resource Economics, University of Florida, Gainesville, FL; Fritz Roka, Associate Professor, Department of Food and Resource Economics, Southwest Florida Research and Education Center, Immokalee, FL; and Carol Fountain, Assistant Editor, Department of Food and Resource Economics, University of Florida, Gainesville, FL; Florida Cooperative Extension Service, Institute of Food and Agricultural Sciences, University of Florida, Gainesville, FL.

This document is designed to provide accurate, current, and authoritative information on the subject. However, since the laws, administrative rulings, and court decisions on which it is based are subject to constant revision, portions of this publication could become outdated at any time. This publication is distributed with the understanding that the authors are not engaged in rendering legal or other professional advice, and the information contained herein should not be regarded as a substitute for professional advice. For these reasons, the utilization of these materials by any person constitutes an agreement to hold harmless the authors, the Institute of Food and Agricultural Sciences, and the University of Florida for any liability claims, damages, or expenses that may be incurred by any person as a result of reference to or reliance on the information contained in this publication.

The Institute of Food and Agricultural Sciences is an equal opportunity/affirmative action employer authorized to provide research, educational information and other services only to individuals and institutions that function without regard to race, color, sex, age, handicap, or national origin. For information on obtaining other extension publications, contact your county Cooperative Extension Service office. Florida Cooperative Extension Service/Institute of Food and Agricultural Sciences/University of Florida/Christine Taylor Waddill, Dean. 
- Not be regrooved, retreaded, or recapped on the front wheels.

- Passenger compartment must have:

- A smooth floor without cracks or holes and without protruding obstructions more than two inches high.

- Sidewalls at least sixty inches high and openings in stake body no more than six inches wide.

- Floors and interiors free of inwardly protruding nails, screws, splinters, or projecting objects.

- Passenger seats securely fastened to vehicle. These seats shall be between sixteen to nineteen inches above the floor with back rests at least thirty-six inches above the floor and shall have a seating depth of at least thirteen inches. Seats shall be at least twenty-four inches apart or eighteen inches when face to face with cracks no more than one-quarter inch on the seat and two inches on the back. Surfaces must be smooth and free of splinters.

-When necessary, passenger protection from inclement weather, using a top at least eighty inches high with provisions for closing sides and ends.

- An opening for entry or exit at the rear or right side that shall be at least eighteen inches wide and at least sixty inches high and have a door or gate with an operable latch.

- Ladders or steps with footholds no more than twelve inches apart; lowest foothold or step shall be no more than eighteen inches from the ground.

- Handholds to permit entry and exit without hazard to passengers.

- Emergency exits in addition to the exit described in number 6 for vehicles with permanent roofs.
- The means to enable passengers to communicate with driver.

- A safe heating method to protect passengers from cold or undue exposure. These types of heaters are FORBIDDEN:

- Exhaust heaters.

- Open flame heaters.

- Heaters permitting fuel leakage.

- Heaters permitting air contamination.

- Unattached heaters.

\section{Related Information}

- Chapters 316.003, 316.620, and 316.450, Florida Statutes.

- Labor Bulletin No. 339, Florida Fruit and Vegetable Association, Orlando, FL, October $31,1974$.

- Commercial Driver's License: Manual for Truck and Bus Drivers, Florida Department of Highway Safety and Motor Vehicles, November 1989.

\section{Responsible Agency}

Florida Department of Highway Safety and Motor Vehicles

Neil Kirkman Building, 2900 Apalachee Parkway

Tallahassee, FL 32399-0500

(850) 488-5370

http://www.hsmv.state.fl.us

For local offices, see the telephone directory under

- Florida, State of

- Highway Patrol 